\title{
Bromodomain-Containing Protein 9
}

National Cancer Institute

\section{Source}

National Cancer Institute. Bromodomain-Containing Protein 9. NCI Thesaurus. Code C157085

Bromodomain-containing protein 9 (597 aa, $\sim 67 \mathrm{kDa}$ ) is encoded by the human BRD9 gene. This protein plays a role in transcriptional regulation, acylated histone binding and chromatin remodeling. 